\title{
Divergent Regulation of Alveolar Type 2 Cell and Fibroblast Apoptosis by Plasminogen Activator Inhibitor 1 in Lung Fibrosis
}

\author{
Chunsun Jiang, ${ }^{*}$ Gang Liu, ${ }^{*}$ Lu Cai, ${ }^{\dagger}$ Jessy Deshane, ${ }^{*}$ Veena Antony, ${ }^{*}$ Victor J. Thannickal, ${ }^{*}$ and Rui-Ming Liu*
}

From the Division of Pulmonary, Allergy, and Critical Care, * Department of Medicine, School of Medicine, University of Alabama at Birmingham, Birmingham, Alabama; and the Pediatric Research Institute, ${ }^{\dagger}$ Department of Pediatrics of the University of Louisville School of Medicine, Louisville, Kentucky

\author{
Accepted for publication \\ April 2, 2021. \\ Address correspondence to Rui- \\ Ming Liu, M.D., Ph.D., \\ Department of Medicine, Uni- \\ versity of Alabama at Birming- \\ ham, Birmingham, AL 35294- \\ 0006. E-mail: rliu@uab.edu.
}

\begin{abstract}
Increased apoptosis sensitivity of alveolar type 2 (ATII) cells and increased apoptosis resistance of (myo)fibroblasts, the apoptosis paradox, contributes to the pathogenesis of idiopathic pulmonary fibrosis (IPF). The mechanism underlying the apoptosis paradox in IPF lungs, however, is unclear. Aging is the greatest risk factor for IPF. In this study, we show, for the first time, that ATII cells from old mice are more sensitive, whereas fibroblasts from old mice are more resistant, to apoptotic challenges, compared with the corresponding cells from young mice. The expression of plasminogen activator inhibitor 1 (PAI-1), an important profibrogenic mediator, was significantly increased in both ATII cells and lung fibroblasts from aged mice. In vitro studies using PAI-1 siRNA and active PAI-1 protein indicated that PAI-1 promoted ATII cell apoptosis but protected fibroblasts from apoptosis, likely through dichotomous regulation of $\mathrm{p} 53$ expression. Deletion of PAI-1 in adult mice led to a reduction in p53, p21, and Bax protein expression, as well as apoptosis sensitivity in ATII cells, and their increase in the lung fibroblasts, as indicated by in vivo studies. This increase was associated with an attenuation of lung fibrosis after bleomycin challenge. Since PAI-1 is up-regulated in both ATII cells and fibroblasts in IPF, the results suggest that increased PAI-1 may underlie the apoptosis paradox of ATII cells and fibroblasts in IPF lungs. (Am J Pathol 2021, 191: 1227-1239; https://doi.org/10.1016/ j.ajpath.2021.04.003)
\end{abstract}

Apoptosis of alveolar type II (ATII) epithelial cells is evident in idiopathic pulmonary fibrosis (IPF). ${ }^{1-3}$ In contrast, (myo)fibroblasts, the major producers of extracellular matrix proteins, from IPF lungs, are resistant to apoptosis. ${ }^{3-5}$ Recurrent injury to alveolar epithelium (apoptosis), followed by sustained activation of (myo)fibroblasts (resistance to apoptosis), is a key factor in the initiation and progression of IPF. However, the mechanism underlying the increased apoptosis sensitivity of ATII cells and increased apoptosis resistance of lung fibroblasts in IPF, referred to as the apoptosis paradox, ${ }^{6}$ is unclear. As broadly targeting apoptosis may worsen fibrosis, identifying the pathways that control the apoptosis paradox in IPF lungs will be critical not only for elucidation of the etiology but also for the development of effective treatments for IPF.

The incidence of and mortality due to IPF increases with advanced age, ${ }^{7-9}$ suggesting that aging is a major risk factor for IPF. The mechanism underlying the age-related susceptibility to IPF is unclear. Plasminogen activator inhibitor 1 (PAI-1) is a primary inhibitor of urokinase-type and tissue-type plasminogen activators, which convert plasminogen into plasmin, a serine protease involved in fibrinolysis. Besides inhibition of fibrinolysis, PAI-1 is also involved in the regulation of cell adhesion, migration, senescence, and apoptosis, dependent and independent of its anti-protease activity. More importantly, PAI-1 expression increases with age in humans and in wild-type and aging model mice as well as in aging-related diseases, including IPF. ${ }^{10-13}$ An increased PAI-1 expression is also detected in experimental fibrosis models induced by different

Supported by NIH grants HL088141 and R56HL131054 as well as Department of Defense grant PR190313 (R.-M.L.); and NIH grant HL114470 (V.J.T.).

Disclosures: None declared. 
stimuli. ${ }^{13-15}$ Deletion of PAI-1 or inhibition of PAI-1 activity attenuates, whereas overexpression of PAI-1 enhances, lung fibrotic responses. ${ }^{13,15-20}$ Together, these data suggest that increased PAI-1 may contribute to the agerelated susceptibility to IPF, although the underlying mechanism remains elusive.

As PAI-1 modulates the sensitivity of different types of cells to apoptosis ${ }^{13,15,21-25}$ and PAI-1 expression is increased in both ATII cells ${ }^{20}$ and lung fibroblasts ${ }^{22}$ in IPF, we hypothesize that increased PAI-1 expression underlies the apoptosis paradox of ATII cells and fibroblasts in IPF lung. Whether ATII cells from old mice were more sensitive, and fibroblasts from old mice were more resistant, to apoptotic stimuli, compared with the corresponding cells from young mice, was investigated. Whether increased PAI1 plays a role in the apoptosis paradox of ATII cells and fibroblasts was tested using genetic and pharmacologic approaches to modulate PAI-1 expression/activity in vitro and in vivo. Our results provide new insights into the potential mechanisms underlying the apoptosis paradox observed in IPF and aging lungs.

\section{Materials and Methods}

\section{Isolation of Fibroblasts and ATII Cells from Mouse Lung}

Mouse lung fibroblasts and ATII cells were isolated following the protocol described previously. ${ }^{20}$ Briefly, mouse lungs were instilled with protease solution (300 U/ $\mathrm{mL}$ collagenase type I, $4 \mathrm{U} / \mathrm{mL}$ elastase, $5 \mathrm{U} / \mathrm{mL}$ dispase, and $100 \mu \mathrm{g} / \mathrm{mL}$ DNase I in Hanks' balanced salt solution), minced by razor, and incubated at $37^{\circ} \mathrm{C}$ for 25 minutes. Digestion was stopped with 50\% Dulbecco's modified Eagle's medium (DMEM)/50\% F12 containing 3\% fetal bovine serum (FBS). The suspension was washed and then incubated with Hanks' balanced salt solution containing $0.1 \%$ trypsin-EDTA and $100 \mu \mathrm{g} / \mathrm{mL}$ DNase I for 20 minutes at $37^{\circ} \mathrm{C}$. Following tissue dissociation, cell suspensions were filtered through a $40-\mu \mathrm{m}$ nylon mesh, washed, and treated with ACK $\left(150 \mathrm{mmol} / \mathrm{L} \quad \mathrm{NH}_{4} \mathrm{Cl}, 10 \mathrm{mmol} / \mathrm{L}\right.$ $\mathrm{KHCO}_{3}$, and $0.1 \mathrm{mmol} / \mathrm{L}$ EDTA) solution to lyse red blood cells and then suspended in DMEM/F12 medium containing $1 \%$ FBS. Macrophages and lymphocytes were removed by incubation with biotinylated rat anti-mouse CD45 and rat anti-mouse CD16/32 (BD Biosciences, San Jose, CA). The cells were then cultured in DMEM/F-12 medium containing $10 \%$ FBS in $100-\mathrm{mm}$ culture dishes at $37^{\circ} \mathrm{C}$ overnight. The suspended ATII cells were transferred to new plates for further treatment. Mouse lung fibroblasts were isolated, as we have described previously. ${ }^{13}$ Briefly, mouse lungs were minced and incubated with the digestion solution $(1 \mathrm{mg} / \mathrm{mL}$ collagenase and $0.05 \%$ trypsin in Hanks' balanced salt solution) at $37^{\circ} \mathrm{C}$ for 60 minutes. The digested tissues were passed through $100-\mu \mathrm{m}$ cell strainers, and cells were spun down and cultured in DMEM/F12 culture medium supplemented with $10 \%$ FBS. Cells between passages 2 and 4 were used for all of the experiments.

\section{Treatment of Cells with Hydrogen Peroxide and Bleomycin}

After isolation, lung fibroblasts and ATII cells were cultured in the DMEM/F12 medium containing $10 \%$ FBS in the plates coated with matrix protein fibronectin $(50 \mu \mathrm{g} / \mathrm{mg})$, collagen $(50 \mu \mathrm{g} / \mathrm{mL})$, or vitronectin $(5 \mu \mathrm{g} / \mathrm{mL})$ for 24 to 48 hours. Cells were then treated with $600 \mu \mathrm{mol} / \mathrm{L} \mathrm{H}_{2} \mathrm{O}_{2}$ or 50 $\mathrm{mU}$ bleomycin in FBS-free medium for 1 day. Human lung fibroblasts (CCL-210 cells) and rat ATII (L2) cells were treated with hydrogen peroxide or bleomycin at the concentrations indicated in the figure legends for 24 hours in the serum-free medium with or without human PAI-1 (hPAI-1; $1 \mu \mathrm{g} / \mathrm{mL}$ ) or $25 \mathrm{mmol} / \mathrm{L}$ TM5275. Alternatively, L2 cells and fibroblasts were transfected with PAI-1 siRNA or nontargeted siRNA and then treated with hydrogen peroxide or bleomycin for 24 hours.

\section{Flow Cytometry Analysis of Apoptotic Cells}

Apoptosis of fibroblasts and ATII cells was analyzed by flow cytometry techniques using Alexa Fluor 488 Annexin V/Dead Cell Apoptosis Kit (Invitrogen, Carlsbad, CA), as described previously. ${ }^{15}$ Briefly, after treatment, the cells were trypsinized, spun down, and incubated with $1 \times$ annexin-binding buffer for 15 minutes, then with Alexa Fluor 488 annexin $\mathrm{V}$ and propidium iodide (PI) working solution at room temperature for another 15 minutes. Annexin-binding buffer was added, and the cells were kept on ice for 15 minutes. Apoptotic cells were analyzed with flow cytometry at University of Alabama at Birmingham (UAB) Flow Cytometer facility. The results are expressed as the percentages of early (quadrant 2) plus later (quadrant 4) apoptotic cells relative to the corresponding controls.

\section{Measurement of Caspase 3/7 Activity in the Conditional Medium}

The activity of caspase $3 / 7$ in the cultured medium was assessed using an assay kit from Promega (Madison, WI; Caspase-Glo 3/7 Assay), according to the manufacturer's protocol.

\section{Western Blot Analysis}

Lung tissues were homogenized in $0.25 \mathrm{~mol} / \mathrm{L}$ sucrose buffer, whereas cells were lysed with cell lysis buffer containing protease inhibitor (Sigma, St. Louis, MO; P8340) and phosphatase inhibitor cocktails (Sigma; P5726). For tissue samples, the homogenates were centrifuged at $3000 \times g, 4^{\circ} \mathrm{C}$, for 10 minutes, followed by a centrifugation at $100,000 \times g$ for 60 minutes. 
Protein concentrations were measured using a bicinchoninic acid protein assay kit (Pierce, Rockford, IL). Protein $(50 \mu \mathrm{g})$ was resolved onto a 10\% SDS-PAGE gel and electrophoretically transferred onto polyvinylidene difluoride membranes, which were probed with the following antibodies: PAI-1 (Molecular Innovation, Novi, MI; ASMPAI-GF), p53 (Santa Cruz Biotechnology, Dallas, TX; SC-6243), p21 (Santa Cruz Biotechnology; SC397), procollagen $1 \alpha 1$ (Santa Cruz Biotechnology; SC8784-R), fibronectin (BD Biosciences; 610077), and $\beta$ actin (Sigma; A5441; protein loading control), and then with the corresponding horseradish peroxidase-conjugated secondary antibodies. The protein bands were visualized using the electrochemiluminescence detection system (Amersham, Piscataway, NY), semiquantified using ImageJ version $1.53 \mathrm{c}$ software $(\mathrm{NIH}$, Bethesda, MD: https://imagej.nih.gov/ij, last accessed October 29, 2020), and normalized by $\beta$-actin.

\section{Generation of Whole Body PAI-1 CKO Mice and Induction of Lung Fibrosis}

Mice bearing the conditional PAI-1 knockout allele (PAI$1^{\text {flox }}$ ) were generated as described previously. ${ }^{20}$ Homozygous PAI-1 floxed $\left(\mathrm{PAI}-1^{\mathrm{t} / \mathrm{fl}}\right)$ mice were crossed with tamoxifen (Tmx)-inducible chicken $\beta$-actin promoter/ enhancer-driven Cre recombinase expressing mice (CagCreER, JAXMICE) to generate tamoxifen-inducible whole body PAI-1 conditional knockout (PAI-1 CKO) mice. Enzyme-linked immunosorbent assay and Western blot analysis were conducted to confirm Tmx-inducible PAI-1 conditional knockout phenotype in different tissues/organs and in isolated fibroblasts as well as ATII cells after mice were injected with tamoxifen or oil. For induction of lung fibrosis, 6- to 8-week-old wild-type (PAI- ${ }^{\mathrm{ft} / \mathrm{fl}}$ ) and PAI-1 CKO mice were injected with Tmx $(100 \mathrm{mg} / \mathrm{kg}$, intraperitoneally) for 7 consecutive days and then challenged with 2 $\mathrm{U} / \mathrm{kg}$ of bleomycin or saline, as we have described previously. ${ }^{20}$ Mice were sacrificed 14 days after bleomycin challenge. Bronchoalveolar lavage (BAL) was performed and then pulmonary artery vascular beds were perfused. Left lung was fixed with $10 \%$ phosphate-buffered saline buffered formalin, and the rest of the lung was frozen immediately in liquid nitrogen. All procedures involving animals were approved by the Institutional Animal Care and Use Committees at the University of Alabama at Birmingham and conducted at the UAB animal facilities under specific pathogen-free conditions.

\section{Total and Differential Cell Counts in BAL Fluid}

BAL fluid was spun down at $400 \times g$ for 10 minutes, and the cells were uniformly suspended in saline. Total cell numbers were counted using a hemocytometer, whereas differential cell counts were determined after the cells were centrifuged onto a microscope slide using a CytoSpin
(HemoCue, Brea, CA) and stained with Protocol HEMA3 (Fisher Scientific, Kalamazoo, MI, Protocol catalog number 123-869). Five hundred cells were counted on each slide using oil immersion $(\times 100)$ lens of Zeiss microscope (Carl Zeiss, San Diego, CA), and the differential cell count was performed. The percentages of neutrophils, lymphocytes, and monocytes were calculated.

\section{Collagen Staining}

Collagen deposition was measured by Masson's trichrome staining, as described previously. ${ }^{15}$

\section{Measurement of Hydroxyproline}

The hydroxyproline content in mouse lung was measured using the Hydroxyproline Assay Kit from Chrondrex, Inc. (Woodinville, WA; catalog number 6017), according to the protocol provided by the manufacturer. The results were calculated on the basis of the standard curves derived from 4-hydroxy-L-proline.

\section{Statistical Analysis}

Data are presented as means $\pm \mathrm{SD}$ and evaluated by one-way analysis of variance. Statistical significance was determined post hoc by Fisher least significant difference test, wherein $P<0.05$ was considered significant.

\section{Results}

Aging Is Associated with Increased Resistance of Lung Fibroblasts but Increased Sensitivity of ATII Cells to Apoptosis

To explore the mechanism underlying the aging-related susceptibility to IPF, apoptosis sensitivities of mouse lung fibroblasts and ATII cells from young (3 months) and old (18 months) mice were assessed by flow cytometry and caspase $3 / 7$ activity after being challenged with hydrogen peroxide or bleomycin in vitro. Treatment of lung fibroblasts with hydrogen peroxide (Figure 1, A and B, and Supplemental Figure S1A) or bleomycin (Figure 1, C and D, and Supplemental Figure S1B) stimulated apoptotic cell death and increased the activity of caspase $3 / 7$, an apoptosis indicator, in fibroblasts from both young and old mice. However, the apoptotic response was significantly lower in fibroblasts from old mice compared with those from young mice. Both stimuli also increased apoptotic cell death in ATII cells from young and old mice (Figure 1, E-H, and Supplemental Figure S1, C and D). In contrast to fibroblasts, ATII cells from old mice were more sensitive to hydrogen peroxide- (Figure 1, E and F, and Supplemental Figure S1C) and bleomycin- 
A

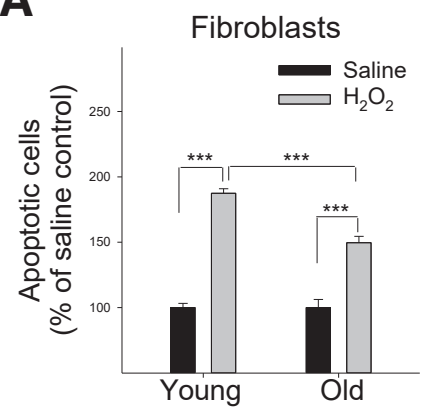

E

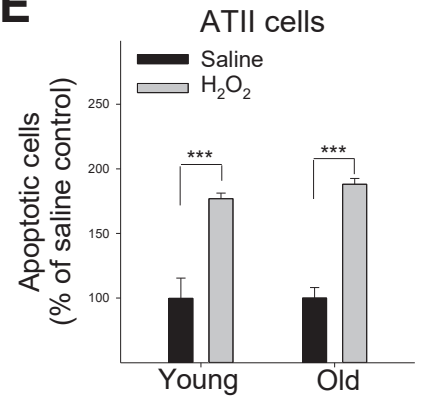

B

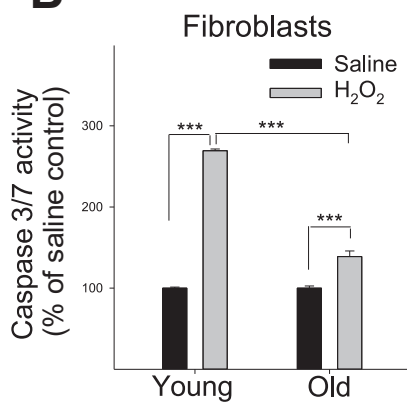

F

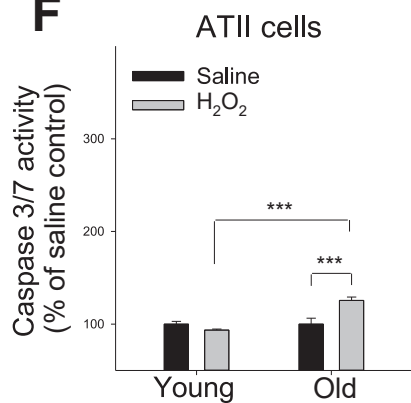

C

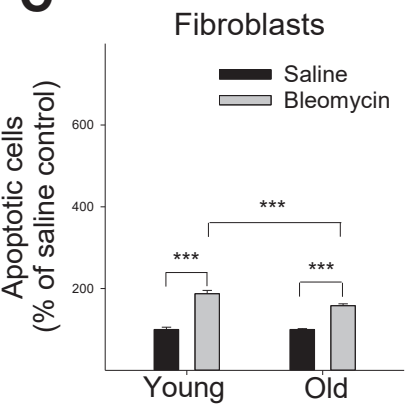

G

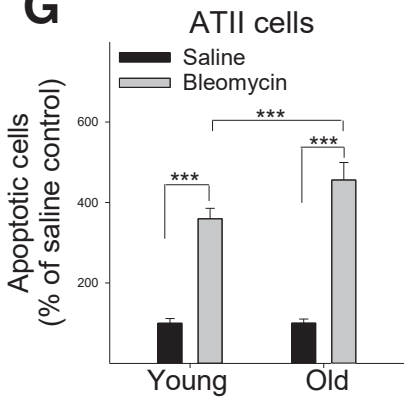

D
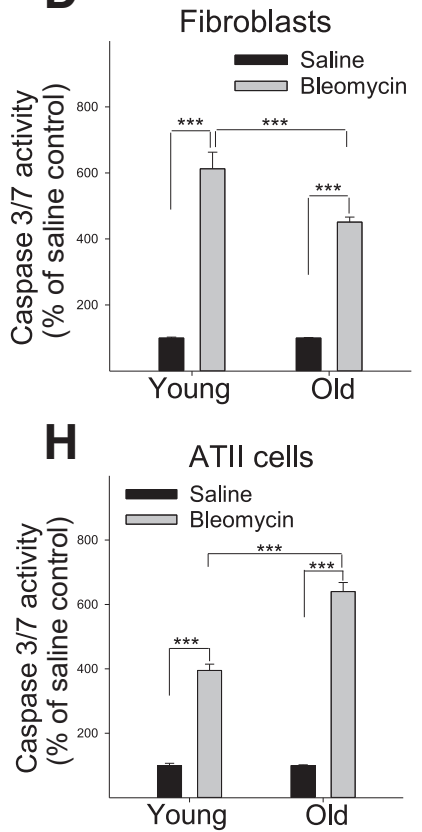

Figure 1 Aging is associated with increased resistance of lung fibroblasts but increased sensitivity of ATII cells to apoptotic challenges. Lung fibroblasts and ATII cells were isolated from 3-month-old and 18-month-old mice and treated with $600 \mu \mathrm{mol} / \mathrm{L} \mathrm{H}_{2} \mathrm{O}_{2}$ or $50 \mathrm{mU} / \mathrm{mL}$ bleomycin in fibronectin-coated plates for 24 hours (four wells per age per treatment group). Apoptotic cell death (A, C, E, and G) and caspase $3 / 7$ activity (B, D, F, and $\mathbf{H}$ ) were assessed by flow cytometry and an Apoptosis Kit from Invitrogen. The results are expressed as percentages of saline-treated controls. $n=4$ (A-H). $* * * P<0.001$.

(Figure 1, G and H, and Supplemental Figure S1D) induced apoptosis than ATII cells from young mice. These data suggest that the apoptosis paradox is a feature of aging lung.

\section{PAI-1 Protein Levels Are Increased with Age in Lung} Fibroblasts and ATII Cells in Mice

To elucidate the potential mechanisms underlying the divergent regulation of apoptosis sensitivity of lung fibroblasts and ATII cells in aged mice, PAI-1 protein content was measured in lung fibroblasts and ATII cells isolated from young and old mice. PAI-1 protein levels increased with age in both lung fibroblasts and ATII cells in mice (Figure 2).

\section{PAI-1 Suppresses p53 Phosphorylation/Expression and Reduces the Apoptosis Sensitivity in Human Lung Fibroblasts}

To determine whether increased PAI-1 is responsible for apoptosis resistance of fibroblasts, human lung fibroblasts (CCL-210; ATCC, Manassas, VA) were treated with hydrogen peroxide in the presence of active hPAI-1 or a small-molecule PAI-1 inhibitor, TM5275, and the corresponding vehicle. Additionally, CCL-210 cells were transfected with PAI-1 siRNA or nontargeted siRNA and then treated with hydrogen peroxide. Treatment of CCL-210 cells with hPAI-1 suppressed, whereas treatment with TM5275 stimulated, p53 phosphorylation at serine 15, and p53 expression (Figure 3A). Silencing PAI-1 with PAI-1 siRNA also induced p53 in fibroblasts (Figure 3B).
A

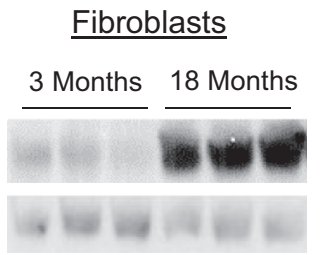

C

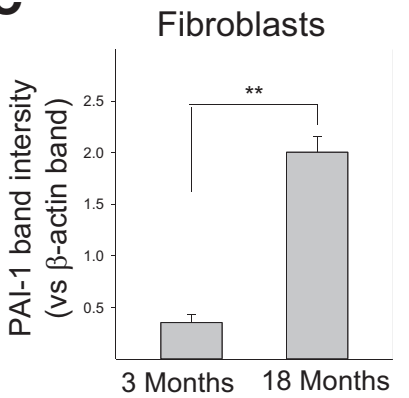

B ATIl cells

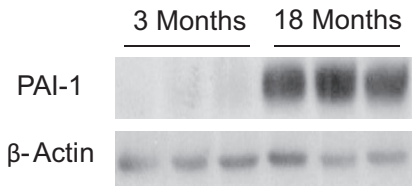

D

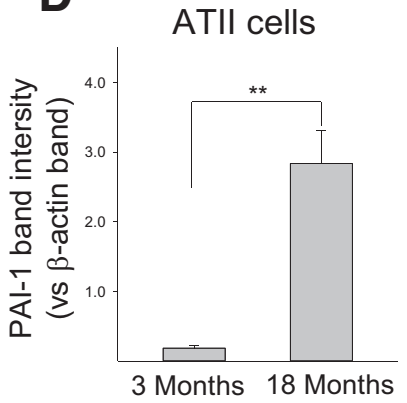

Figure 2 Plasminogen activator inhibitor 1 (PAI-1) protein content increases with age in mouse fibroblasts and ATII cells. Lung fibroblasts (A and $\mathbf{C}$ ) and ATII cells (B and D) were isolated from 3-month-old and 18month-old mice (three mice per group), and PAI-1 protein was assessed by Western blot analysis. $n=3(\mathbf{A}-\mathbf{D})$. ${ }^{* *} P<0.01$. 
Associated with the suppression of p53 phosphorylation/ expression, hPAI- 1 reduced the sensitivity of CCL-210 cells to hydrogen peroxide-induced apoptosis (Figure 3, C and D). Treatment with TM5275 (Figure 3, E and F) or silencing PAI-1 (Figure 3, G and H), on the other hand, enhanced the sensitivity of CCL-210 cells to hydrogen peroxide-induced apoptosis. These results suggest that increased PAI-1 expression/activity may underlie the apoptosis resistance observed in aged fibroblasts.

PAI-1 Induces p53 and Enhances the Sensitivity of Rat ATII (L2) Cells to Bleomycin and Hydrogen

Peroxide-Induced Apoptosis

To delineate the potential relationship between increased PAI-1 and the augmented sensitivity of ATII cells to apoptosis, rat ATII (L2) cells, stably transfected with PAI1 shRNA or nontargeted shRNA, were treated with bleomycin. Alternatively, L2 cells were treated with hydrogen peroxide in the presence or absence of hPAI-1. Silencing PAI-1 with PAI-1 shRNA led to decreases in p53 phosphorylation and p53 protein expression (Figure 4A). This was associated with a reduced sensitivity of L2 cells to bleomycin-induced apoptosis (Figure 4, B and C). Treatment of L2 cells with hPAI-1 alone, on the other hand, stimulated p53 phosphorylation, the expression of p53 and p21 proteins (Figure 4D), and L2 cell apoptosis (Figure 4, E and F). Treatment with hPAI-1 also augmented the apoptosis sensitivity of L2 cells to hydrogen peroxide (Figure 4, E and F) and bleomycin (Figure 4, G and H).

\section{Silencing p53 Blocks PAI-1 Protein-Induced L2 Cell Apoptosis}

The effect of silencing p53 on PAI-1 protein-induced L2 cell apoptosis was tested to delineate the role of PAI-1 in promoting L2 cell apoptosis through p53 induction. Silencing p53 with p53 siRNA partially reduced hydrogen peroxide-induced L2 cell apoptosis (Figure 5, A and B), but completely eliminated hPAI-1-induced L2 cell apoptosis (Figure 5, C and D). Together, these results suggest that PAI-1 promotes ATII cell apoptosis through increasing p53, whereas hydrogen peroxide causes ATII cell apoptosis, in part, through induction of PAI-1 followed by that of $\mathrm{p} 53$.
A

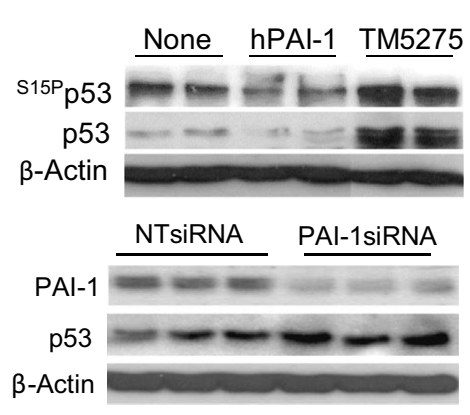

C

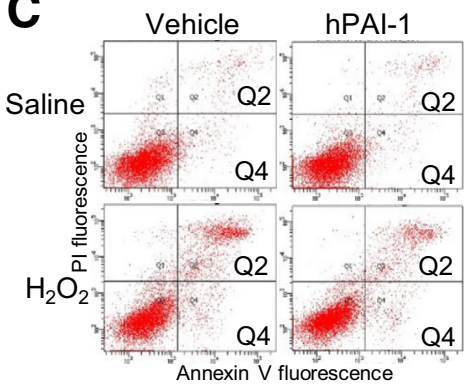

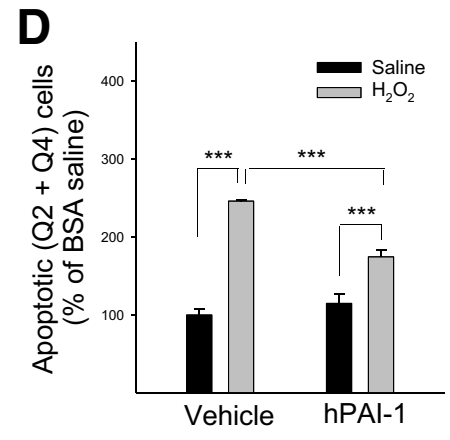
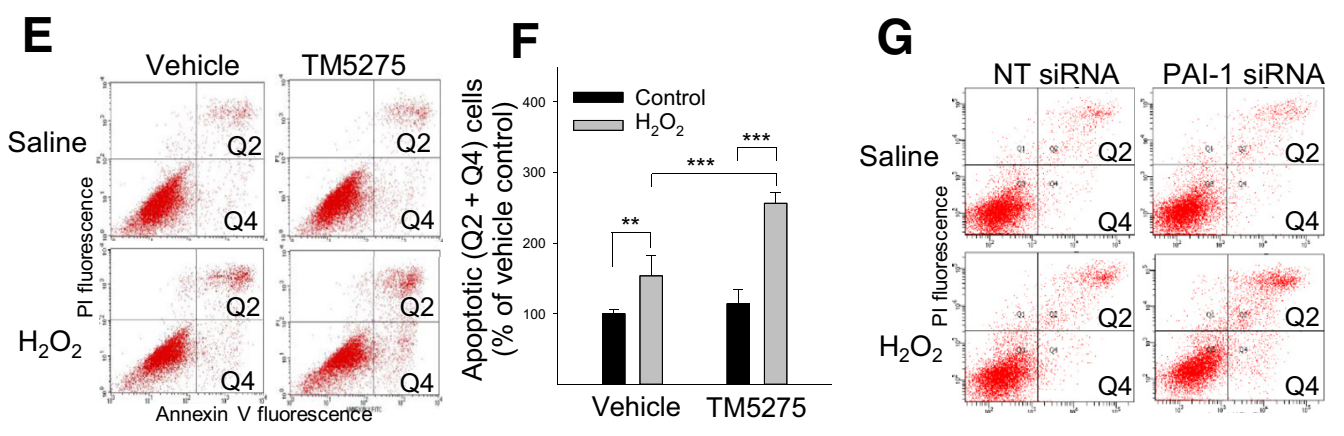

H

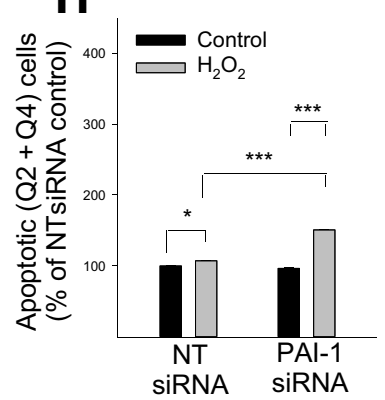

Figure 3 Plasminogen activator inhibitor 1 (PAI-1) reduces $p 53$ phosphorylation and expression as well as the sensitivity to hydrogen peroxide-induced apoptosis in human lung fibroblasts. A and B: Human lung fibroblasts (CCL-210 cells) were treated with $1 \mu \mathrm{g} / \mathrm{mL}$ of active human protein [human PAI-1 (hPAI1)] or $25 \mathrm{mmol} / \mathrm{L}$ TM5275 for 24 hours or transfected with PAI-1 siRNA or nontargeted (NT) siRNA. Western blot analyses of PAI-1, phosphorylated p53, and p53 were performed with cell lysates. $\beta$-Actin was used as protein loading control. $\mathbf{C}$ and $\mathbf{D}$ : $\mathrm{CCL}-210$ cells were treated with $200 \mu \mathrm{mol} / \mathrm{L} \mathrm{H} \mathrm{H}_{2}$ in the presence of hPAI-1 $\left(1 \mu \mathrm{g} / \mathrm{mL}\right.$ ) or bovine serum albumin (BSA; vehicle control) for 24 hours. E and $\mathbf{F}$ : CCL-210 cells were treated with $150 \mu \mathrm{mol} / \mathrm{L} \mathrm{H}_{2} \mathrm{O}_{2}$ in the presence or absence of $25 \mathrm{mmol} / \mathrm{L}$ TM5275 for 24 hours. $\mathbf{G}$ and $\mathbf{H}$ : CCL-210 cells were transfected with PAI-1 siRNA or NT siRNA and then treated with $150 \mu \mathrm{mol} / \mathrm{L} \mathrm{H}_{2} \mathrm{O}_{2}$ for 24 hours, with three to four wells per treatment group. Apoptosis was assessed by flow cytometry, and the results are expressed as the percentages of the corresponding controls. $n=3$ to $4(\mathrm{~A}-\mathrm{H})$. ${ }^{*} P<0.05,{ }^{*} P<0.01$, and ${ }^{*} * * P 0.001$. Q2, quadrant 2; Q4, quadrant 4. 
A

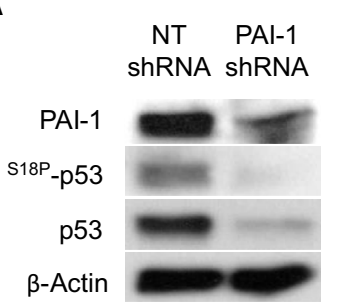

$\mathbf{E}$

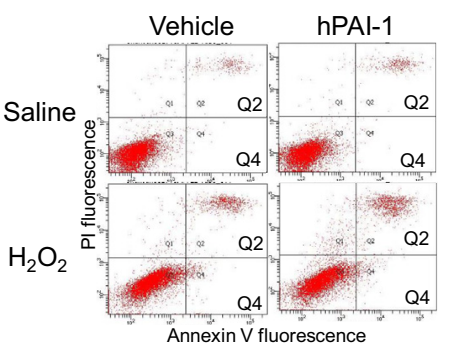

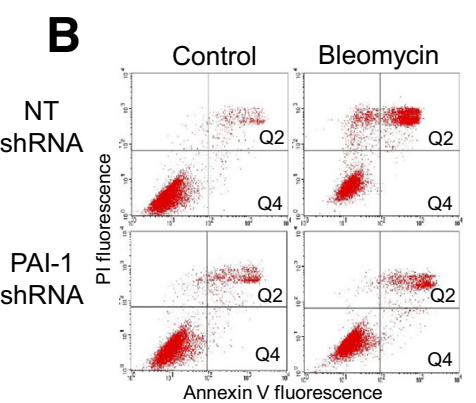
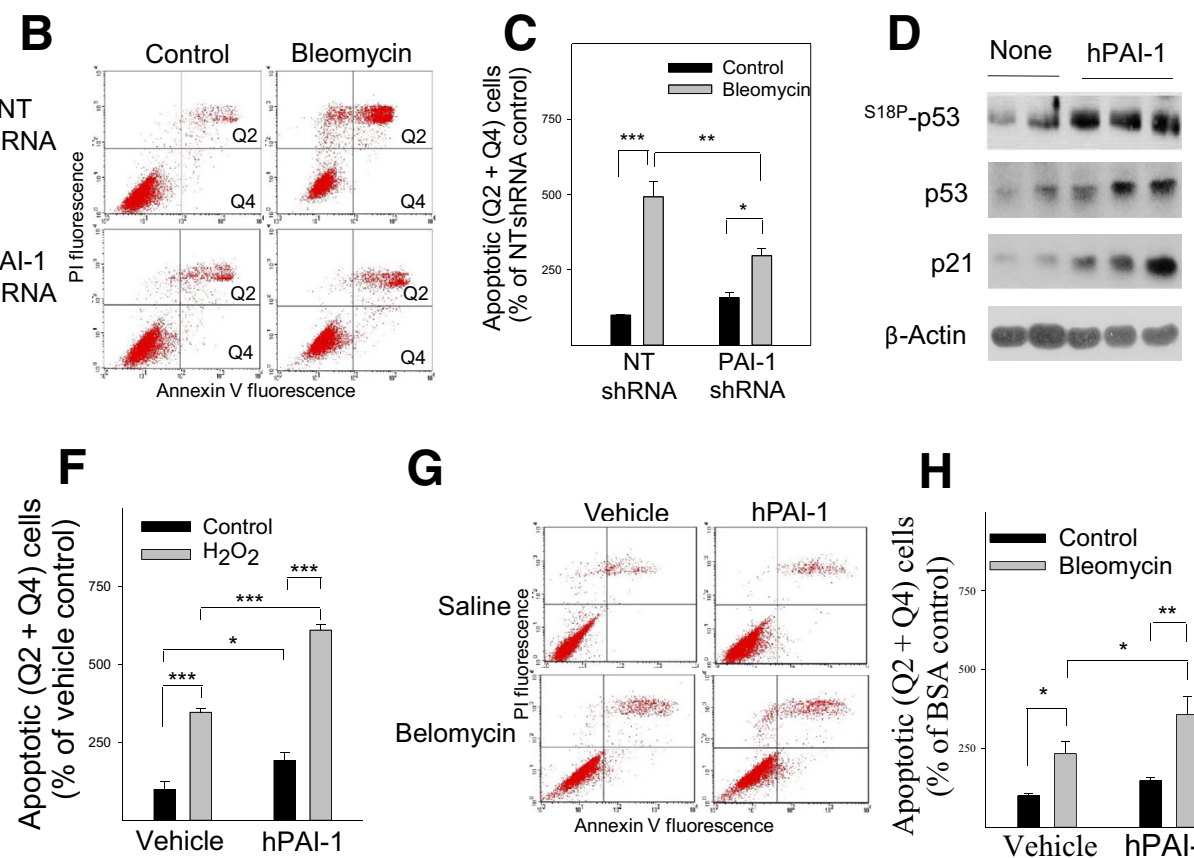

G

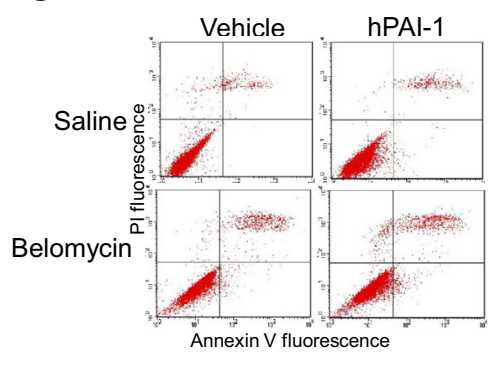

H

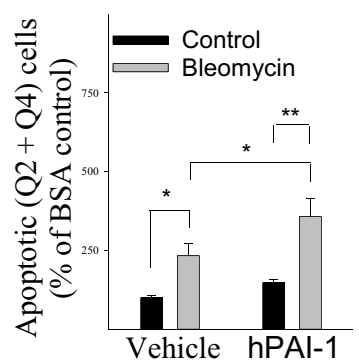

Figure 4 Plasminogen activator inhibitor 1 (PAI-1) induces p53 expression and enhances the sensitivity of rat ATII (L2) cells to bleomycin- and hydrogen peroxide-induced apoptosis. A: Western blot analyses of PAI-1, phosphorylated and total p53, as well as p21 in PAI-1 shRNA stably transfected L2 cells. B and C: L2 cells stably transfected with PAI-1 shRNA or nontargeted (NT) shRNA were treated with $25 \mathrm{mU} / \mathrm{mL}$ bleomycin for 24 hours. D: L2 cells were treated with active human PAI-1 (hPAI-1; $1 \mu \mathrm{g} / \mathrm{mL}$ ) for 24 hours, and Western blot analyses were performed with cell lysates. $\mathbf{E}$ and $\mathbf{F}$ : L2 cells were treated with $200 \mu \mathrm{mol} / \mathrm{L}$ $\mathrm{H}_{2} \mathrm{O}_{2}$ in the presence or absence of hPAI-1 $(1 \mu \mathrm{g} / \mathrm{mL})$ for 24 hours. $\mathbf{G}$ and $\mathbf{H}$ : L2 cells were treated with $50 \mathrm{mU} / \mathrm{mL}$ of bleomycin in the presence or absence of hPAI-1 $(1 \mu \mathrm{g} / \mathrm{mL})$ for 24 hours (three to four wells per treatment group). Apoptosis was assessed by flow cytometry, and the results are expressed as the percentages of the corresponding untreated controls. $n=3$ to 4 (A-H). ${ }^{*} P<0.05,{ }^{*} P<0.01$, and ${ }^{* *} P<0.001$. Q2, quadrant 2 ; Q4, quadrant 4 .

Knockout of the PAI-1 Gene in Adult Mice Leads to Increased p53, p21, and Bax in Lung Fibroblasts, but Decreased p53, p21, and Bax in ATII Cells

To determine whether deletion of PAI-1 in adult mice divergently regulates apoptosis sensitivity of lung fibroblasts and ATII cells, we developed a Tmxinducible whole body PAI-1 conditional knockout mouse model (PAI-1 CKO) by crossing PAI- ${ }^{\mathrm{f} / \mathrm{fl}}$ mice $^{20}$ with tamoxifen-inducible chicken $\beta$-actin promoter/enhancer-driven Cre recombinase-expressing mice. Administration of Tmx to PAI-1 CKO mice, but not PAI- $1^{\mathrm{f} / \mathrm{fl}}$ (wild-type) mice, led to an almost complete elimination of PAI-1 protein from the plasma and lung tissue (Figure 6, A and B), as indicated by the enzyme-linked immunosorbent assay. Additionally, Western blot data showed that Tmx injection dramatically reduces the amounts of PAI-1 protein from lung fibroblasts and ATII cells (Figure 6, C-F). Notably, deletion of PAI-1 led to an increase in the expression of $\mathrm{p} 53, \mathrm{p} 21$, and Bax proteins in fibroblasts, but a decrease in ATII cells (Figure 6, C-F). These data suggest that PAI-1 divergently regulates the expression of p53 in lung fibroblasts and ATII cells in vivo.
Knockout of the PAI-1 Gene in Adult Mice Increases the Sensitivity of Lung Fibroblasts to Apoptosis, but Protects ATII Cells from Apoptotic Challenges

The role of extracellular matrix proteins in response of cells to stimuli is well-documented. Collagen, fibronectin, and vitronectin are three major types of extracellular matrix proteins. PAI-1 modulates cell attachment and activity by binding to vitronectin. However, whether it binds to other matrix proteins, thereby affecting other cell functions, is unclear. To determine whether deletion of PAI- 1 affects the sensitivity of lung fibroblasts and ATII cells to apoptosis stimuli, and whether these effects depend on the matrix proteins, lung fibroblasts and ATII cells were isolated from adult PAI- $1^{\mathrm{f} / \mathrm{fl}}$ (wild-type) and PAI-1 CKO mice after Tmx injection. The isolated cells were treated with bleomycin or hydrogen peroxide in vitro in collagen-, fibronectin-, or vitronectincoated plates. Deletion of PAI-1 enhanced the sensitivity of fibroblasts to hydrogen peroxide- and bleomycin-induced apoptosis when cultured on fibronectin-coated plates (Figure 7, A and B, and Supplemental Figure S2A). The flow cytometry results showed no significant difference between PAI- $1^{+/+}$and PAI- $1^{-/-}$fibroblasts to hydrogen peroxide - or bleomycin-induced apoptosis on collagen-coated plates and 

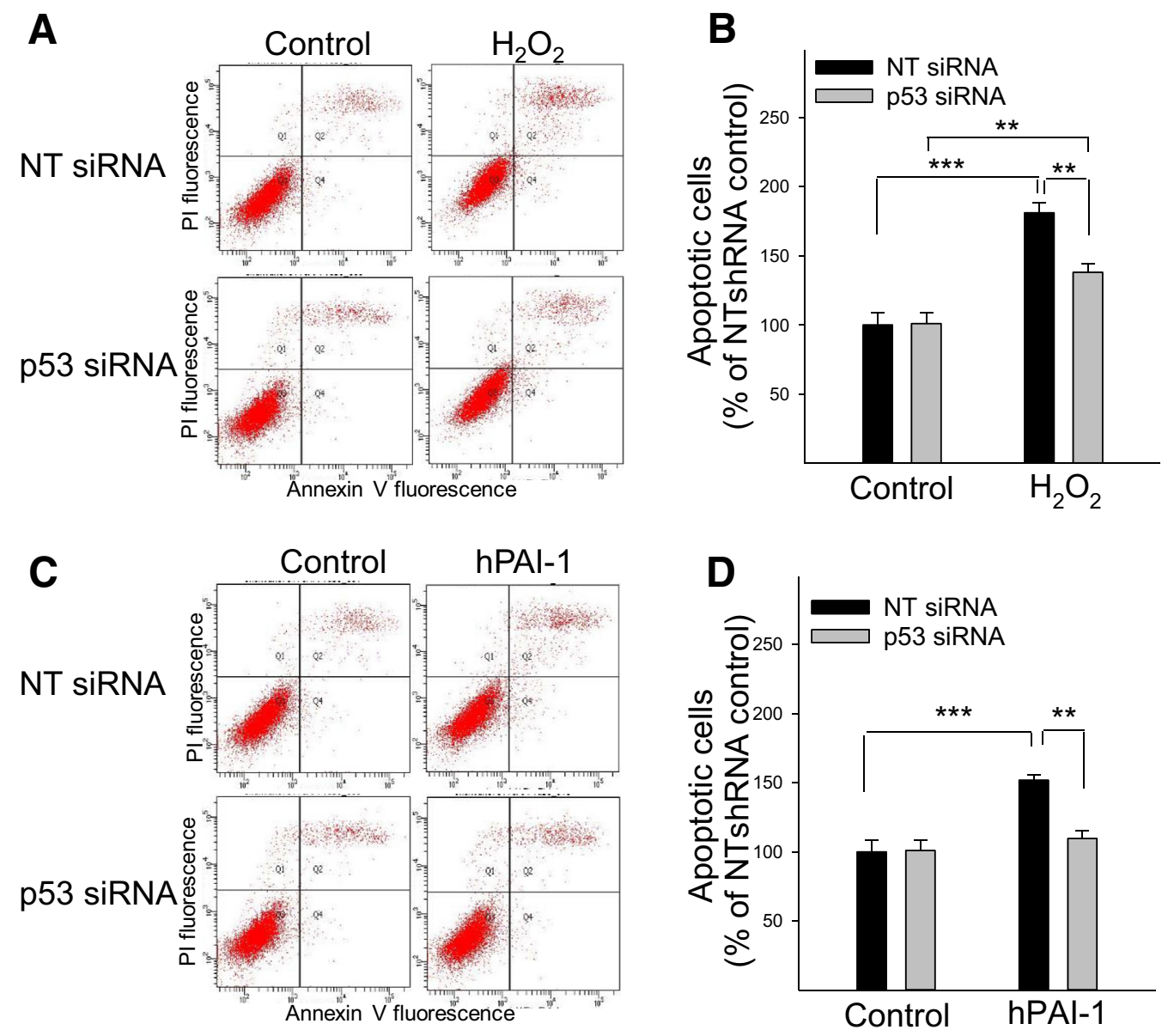

Figure 5 Silencing p53 blocks plasminogen activator inhibitor 1 (PAI-1)-induced L2 cell apoptosis. L2 cells were transfected with p53 siRNA or nontargeted (NT) siRNA and then treated with $150 \mu \mathrm{mol} / \mathrm{L} \mathrm{H}_{2} \mathrm{O}_{2}$ (A and $\mathbf{B}$ ) or $1 \mu \mathrm{g} / \mathrm{mL}$ active human PAI-1 (hPAI-1; C and D) for 24 hours (three wells per treatment group). Apoptotic cells were assessed by flow cytometry. $n=3$ (A-D). ${ }^{* * P}<0.01,{ }^{* * * P}<0.001$.

hydrogen peroxide-induced apoptosis on vitronectin-coated plates (Figure 7, A and B). On the other hand, the caspase 3/7 activity data indicate that knockout of the PAI-1 gene significantly increased the sensitivity of fibroblasts to apoptosis induced by both agents when cultured on collagenor vitronectin-coated plates (Supplemental Figure S2, A and B). These results suggest that the caspase $3 / 7$ activity is more sensitive than annexin $\mathrm{V}$ labeling for the apoptotic response. In contrast to fibroblasts, deletion of PAI-1 significantly reduced the sensitivity of ATII cells to hydrogen peroxideand bleomycin-induced apoptosis in three types of matrix protein-coated plates (Figure 7, C and D, and Supplemental Figure S2, C and D). Together, these results suggest that PAI-1 protects fibroblasts from apoptosis and promotes ATII cell apoptosis independent of matrix proteins.

\section{Knockout of the PAI-1 Gene in Adult Mice Attenuates Bleomycin-Induced Inflammatory Responses and Lung Fibrosis}

As shown in Figure 8, A and B, bleomycin instillation significantly increased the total BAL cell counts (Figure 8A) as well as the neutrophils and lymphocytes (Figure $8 \mathrm{~B}$ ) in BAL fluid. While deletion of PAI-1 significantly attenuated bleomycin-induced neutrophil infiltration, it had no significant effect on bleomycin-induced lymphocyte infiltration (Figure 8, A and B). Ablation of PAI-1 in adult mice also significantly attenuated bleomycin-induced lung fibrosis, as indicated by trichrome staining (Figure $8 \mathrm{C}$ ), Western blot analysis (Figure 8, D and E), and hydroxyproline measurement (Figure $8 \mathrm{~F}$ ).

\section{Discussion}

The apoptosis paradox, which is the increased apoptosis resistance of (myo)fibroblasts, but increased apoptosis sensitivity of ATII cells, is a pathologic feature of IPF. ${ }^{1-5,26}$ The mechanism underlying the apoptosis paradox in IPF is unclear. IPF is considered as a disease of aging ${ }^{27,28}$; the mechanism underlying the aging-related susceptibility to IPF is also unknown. In this study, we show for the first time that ATII cells from old mice are more sensitive, whereas lung fibroblasts from old mice are more resistant, to apoptotic stimuli, compared with the corresponding cells 

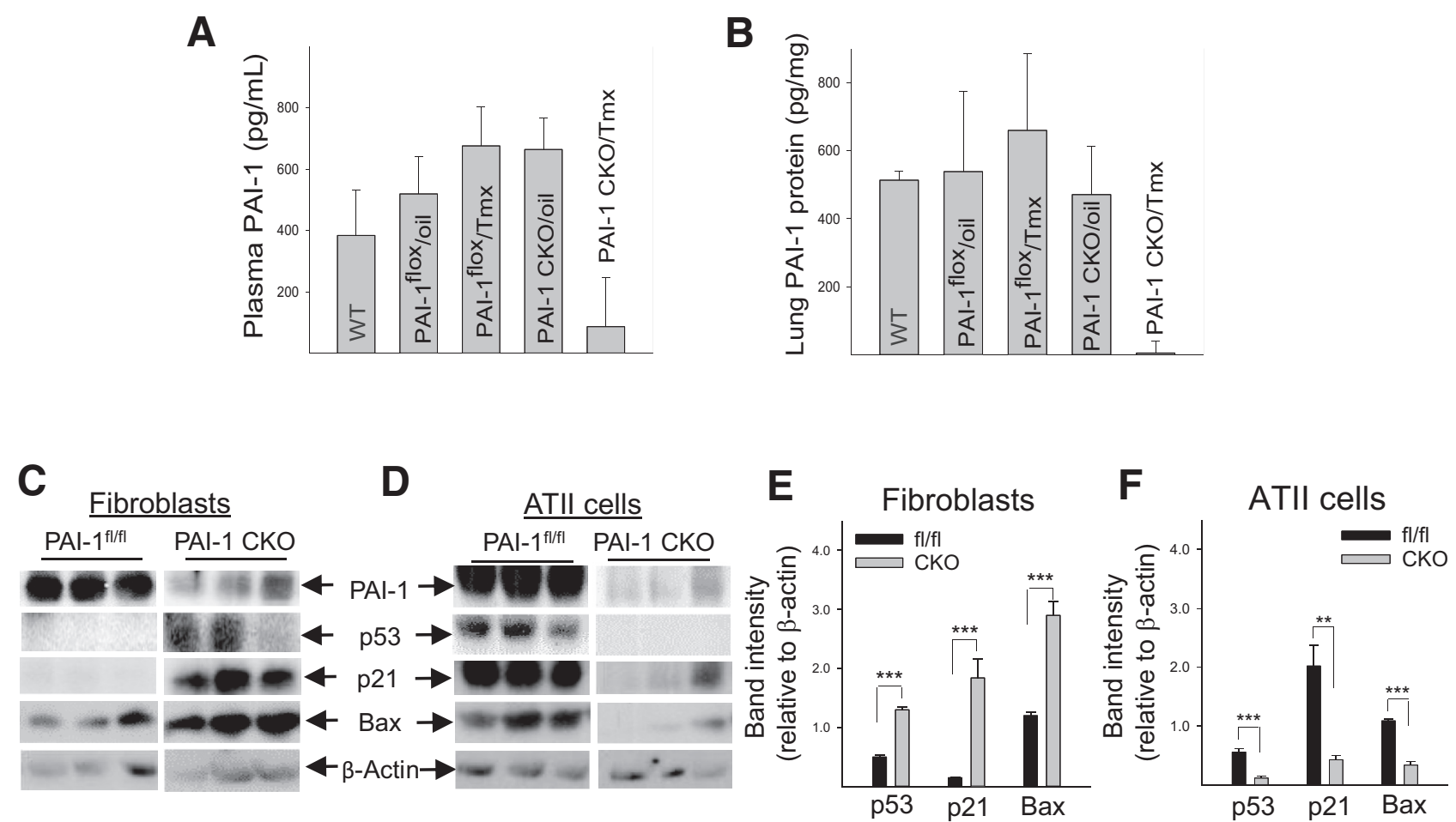

Figure 6 Knockout of the plasminogen activator inhibitor 1 (PAI-1) gene in adult mice leads to increased p53 and Bax expression in lung fibroblasts but decreased $\mathrm{p} 53$ and Bax expression in ATII cells. Adult whole body PAI-1 conditional knockout (CKO) and PAI- ${ }^{\mathrm{fl} / \mathrm{fl}}$ [wild-type (WT) control] mice were intraperitoneally injected with tamoxifen ( $\mathrm{Tmx}$ ) or corn oil (vehicle control) for 7 consecutive days and then sacrificed. A and B: Enzyme-linked immunosorbent assay of PAI-1 in plasma and in lung tissue. C and D: Western blot analysis of the proteins of interest in isolated lung fibroblasts and ATII cells from PAI-1 CKO and PAI- $1^{\mathrm{fl} / \mathrm{fl}}$ mice after Tmx injection. E and F: Semiquantitation of the band intensities of Western blots, normalized with $\beta$-actin bands. $n=6$ to 7 mice per group (A and $\mathbf{B}) ; n=3(\mathbf{C}-\mathbf{F}) .{ }^{* *} P<0.01,{ }^{* *} P<0.001$.

from young mice. These results suggest that the apoptosis paradox is per se a feature of aging lung, and further support the notion that aging is a risk factor for IPF. As indicated by genetic and pharmacologic experiments, PAI-1 promoted ATII cell apoptosis, but protected lung fibroblasts from apoptotic challenges, suggesting that increased PAI-1 may contribute to the apoptosis paradox observed in aging lung and fibrotic lung.

Old animals are more sensitive to bleomycin-induced lung fibrosis. ${ }^{5,13,29}$ The mechanism underlying the agingrelated sensitivity to lung fibrosis, however, is unclear. In this study, we show, for the first time, that PAI-1 expression is increased in both fibroblasts and ATII cells from aged mice, which is associated with an increased apoptosis resistance of lung fibroblasts, but increased apoptosis sensitivity of ATII cells from old mice, compared with the corresponding cells from young mice. The in vitro and in vivo studies further showed that inhibition of PAI-1 activity or silencing/deletion of PAI-1 increases, whereas treatment with active PAI-1 protein reduces, the sensitivity of fibroblasts to apoptosis. In contrast, silencing/deletion of PAI-1 reduced, whereas treatment with active PAI-1 protein increased, the sensitivity of ATII cells to apoptosis. PAI-1 differentially regulated the sensitivity of fibroblasts and
ATII cells to apoptosis, which promotes ATII cell apoptosis, but protects lung fibroblasts from apoptosis. These results further support previous observations in lung fibroblasts from old mice, although no ATII cells were studied at the time. ${ }^{13}$ Similar results showing promotion of ATII cell apoptosis by PAI-1 have been reported by other investigators in young mice. ${ }^{30,31}$ Because PAI-1 expression is increased in lung fibroblasts and ATII cells in IPF lungs ${ }^{20,22}$ the current results suggest that increased PAI-1 expression/activity may be responsible for the apoptosis paradox observed in IPF lungs.

The mechanism underlying the divergent regulation of PAI-1 on apoptosis sensitivity of lung fibroblasts and ATII cells is unclear. p53 is a master regulator of cell cycle and plays a critical role in the control of cell senescence and apoptosis. However, the mechanisms governing the effects of p53 on cell senescence and apoptosis remain elusive. PAI-1 is involved in cell senescence of cardiomyocytes, fibroblasts, and endothelial cells, and inhibition of PAI-1 activity with a small-molecule PAI-1 inhibitor, TM5441, suppresses p53 expression and cell senescence induced by different stimuli. ${ }^{32,33}$ Knockdown of PAI-1 with PAI-1 shRNA or inhibition of PAI-1 activity with tiplaxtinin increases p53 expression and arrests cells in $G_{0}$ phase in 

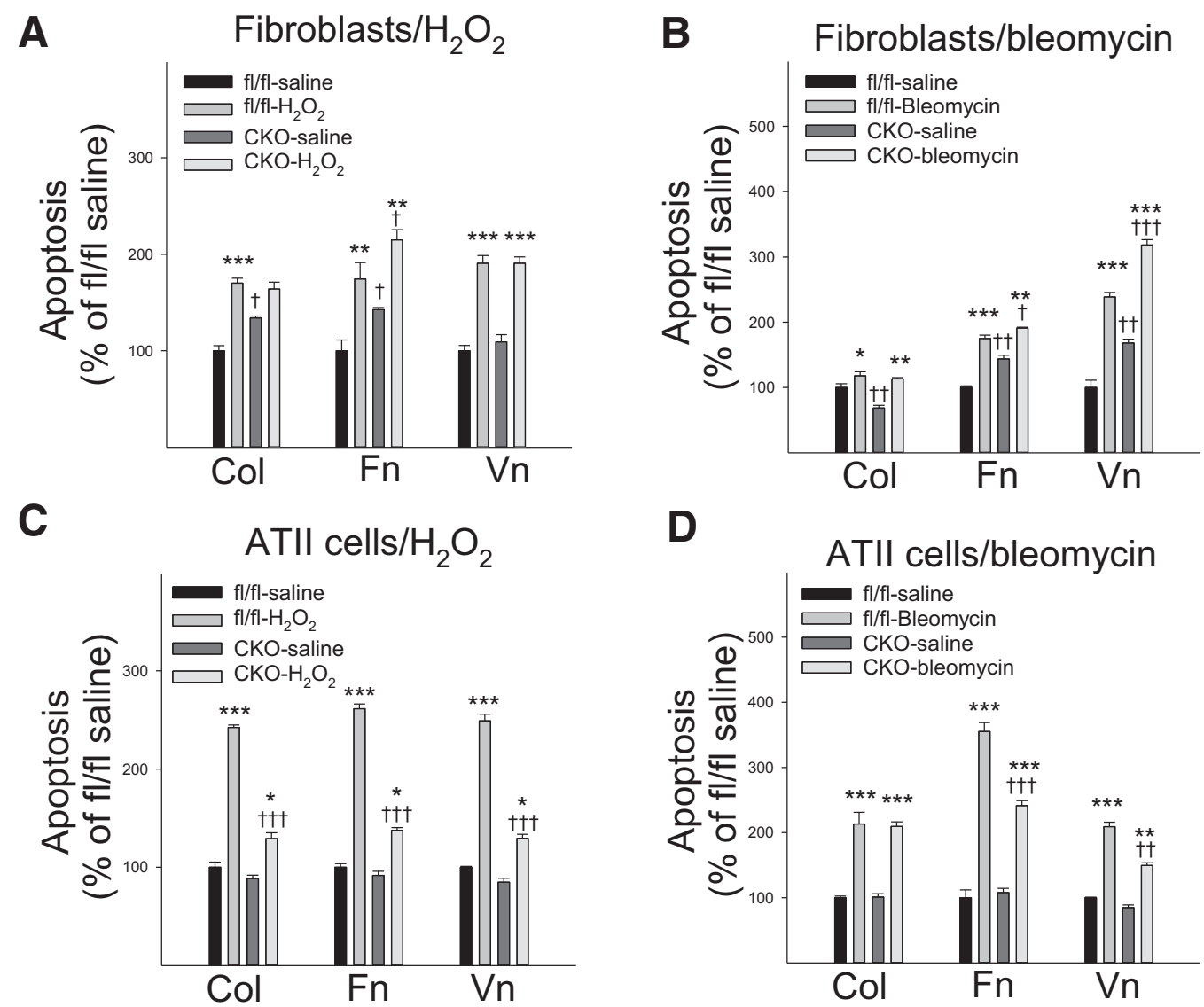

Figure 7 Knockout of the plasminogen activator inhibitor 1 (PAI-1) gene in adult mice promotes lung fibroblast apoptosis, but protects ATII cells from apoptotic challenges. Lung fibroblasts (A and $\mathbf{B})$ and ATII cells (C and $\mathbf{D})$ were isolated from PAI-1 conditional knockout (CKO) and PAI- $1^{\mathrm{fl} / \mathrm{fl}}$ mice after tamoxifen injection and treated with $600 \mu \mathrm{mol} / \mathrm{L} \mathrm{H}_{2} \mathrm{O}_{2}$ (A and $\mathbf{C}$ ) or $50 \mathrm{mU} / \mathrm{mL}$ bleomycin (B and $\left.\mathbf{D}\right)$ for 24 hours on collagen (Col)-, fibronectin (Fn)-, or vitronectin $(\mathrm{Vn})$-coated plates (four wells per matrix per treatment). Apoptotic cells were assessed by flow cytometry, and the results are expressed as percentages of saline-treated PAI- $1^{\mathrm{fl} / \mathrm{fl}}$ fibroblasts/ATII cells. $n=4$ (A-D). ${ }^{*} P<0.05,{ }^{*} P<0.01$, and ${ }^{* *} P<0.001$ (significantly different from the corresponding saline-treated fibroblasts/ATII cells); ${ }^{\dagger} P<0.05,{ }^{\dagger \dagger} P<0.01$, and ${ }^{\dagger \dagger \dagger} P<0.001$ (significantly different from the corresponding PAI- ${ }^{\mathrm{fl} / \mathrm{fl}}$ fibroblasts/ATII cells).

human urothelial cells. ${ }^{34}$ Moreover, PAI-1 binds to $\alpha 3$ subunit of proteasome and inhibits $\mathrm{p} 53$ degradation. ${ }^{35}$ PAI-1 activity leads to an increases in p53 expression and apoptosis in human lung fibroblasts, ${ }^{15}$ whereas deletion of PAI-1 in mouse ATII cells or silencing PAI-1 with PAI-1 siRNA/shRNA in rat ATII (L2) cells attenuates bleomycin-induced $\mathrm{p} 53$ expression. ${ }^{20}$ Together, these data strongly suggest that PAI-1 can positively or negatively regulate p53 expression, depending on cell types and stimuli. The current study indicates that inhibition of PAI-1 activity, silencing PAI-1, or deletion of PAI-1 protein leads to increases in p53 protein as well as the sensitivity of fibroblasts to hydrogen peroxide- or bleomycin-induced apoptosis. Treatment of fibroblasts with active PAI-1 protein, on the other hand, reduced p53 protein and the sensitivity of fibroblasts to hydrogen peroxide-induced apoptosis. In contrast to fibroblasts, silencing PAI-1 suppressed p53 phosphorylation and expression and attenuated bleomycin-induced apoptosis in rat lung ATII (L2) cells. Treatment of L2 cells with active PAI-1, on the other hand, increased p53 phosphorylation, p53 expression, and the sensitivity of L2 cells to hydrogen peroxide-induced apoptosis. Deletion of PAI-1 in adult mice also led to divergent regulation of p53 expression as well as apoptosis sensitivity in mouse ATII cells and lung fibroblasts. Together, these data suggest that the increase in PAI-1 divergently affects the apoptosis sensitivity of lung fibroblasts and ATII cells, at least in part through dichotomous regulation of p53 expression in these cells. More importantly, p53 expression is increased in ATII cells but decreased in fibroblasts, ${ }^{2,36-38}$ whereas PAI- 1 expression is increased in both ATII cells and fibroblasts, ${ }^{20,22}$ in IPF lungs. These observations further support our hypothesis that increased PAI-1 expression may contribute to the apoptosis paradox of ATII cells and lung fibroblasts in IPF through divergent regulation of $\mathrm{p} 53$ expression.

Of note, instead of regulation of $\mathrm{p} 53$ expression by PAI1 , several studies have shown p53 regulation of PAI-1 expression in different cell types. ${ }^{31,39-42}$ PAI-1 expression is low in $\mathrm{p}^{-1-}$ H1299 lung carcinoma cells, and 
A

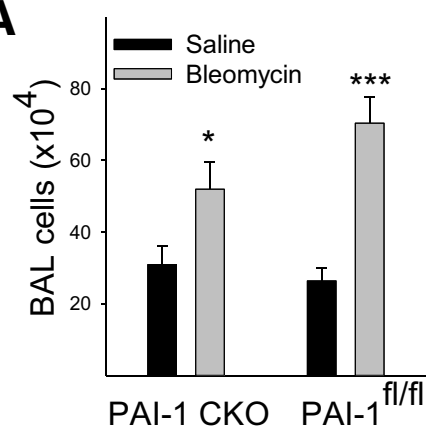

B

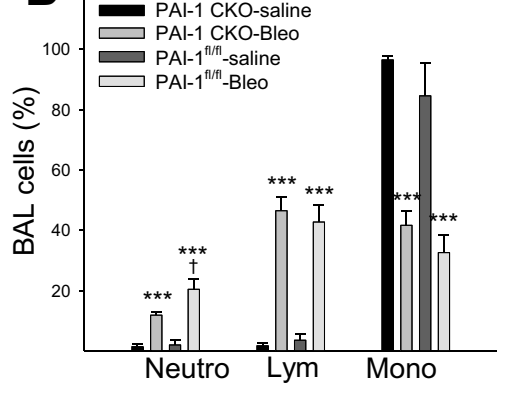

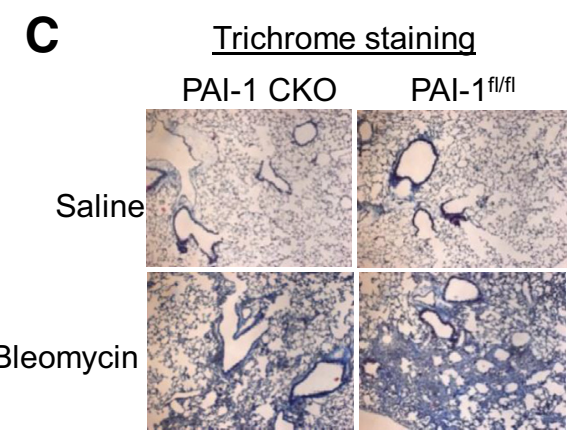
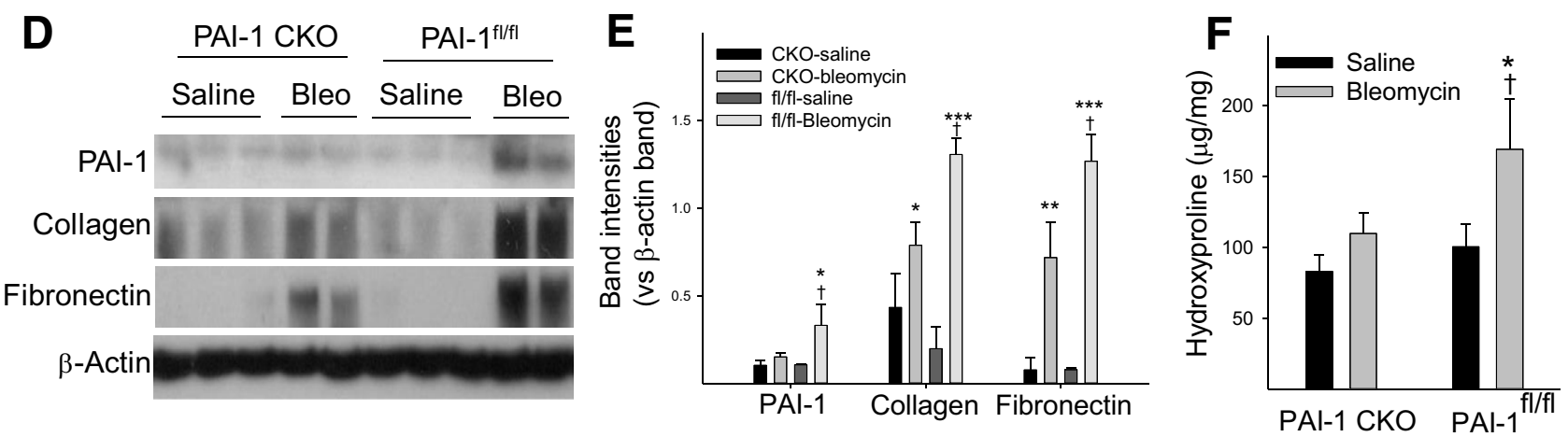

Figure 8 Knockout of the plasminogen activator inhibitor 1 (PAI-1) gene in adult mice attenuates bleomycin (Bleo)-induced inflammatory responses and lung fibrosis. A: Total cell numbers in bronchoalveolar lavage (BAL) fluid. B: Differential cell counts of BAL cells. C: Trichrome staining of collagens. D and E: Western blot analyses of fibrosis-related proteins in mouse lung tissues. F: Hydroxyproline contents in mouse lungs. $n=7$ to $8(\mathbf{A}-\mathbf{C}, \mathbf{F})$ and $\mathrm{n}=4(\mathbf{D}, \mathbf{E})$. ${ }^{*} P<0.05,{ }^{*} P<0.01$, and ${ }^{* * *} P<0.001$ (significantly different from the corresponding saline-treated fibroblasts/ATII cells); ${ }^{\dagger} P<0.05$ (significantly different from the corresponding PAI- $1^{\mathrm{fl} / \mathrm{fl}}$ fibroblasts/ATII cells). CKO, conditional knockout; Lym, lymphocytes; Mono, monocytes; Neutro, neutrophils.

overexpression of p53 significantly increases PAI- $1 .{ }^{40}$ p53 up-regulates PAI-1 expression by binding to the $3^{\prime}$-untranslated region of PAI-1 mRNA, thereby stabilizing the PAI-1 mRNA. ${ }^{40}$ As indicated in cigarette- or bleomycininduced lung injury and fibrosis models, increased p53 induces PAI-1 during ATII cell popotosis. ${ }^{31,43}$ Gene silencing, ablation, and pharmacologic inhibitor studies indicate that p53 mediates transforming growth factor (TGF)- $\beta 1$-induced PAI-1 expression in human renal tumor epithelial cells and keratinocytes. Silencing p53 reduces PAI-1 protein-induced PAI-1 expression in rat ATII (L2) cells ${ }^{20}$ confirming $\mathrm{p} 53$ regulation of PAI-1 expression in ATII cells. Together, these results suggest that there are bidirectional cross talks between p53 and PAI-1. p53 positively regulates PAI-1 expression in different types of cells, whereas PAI-1 may have differential effects on p53 expression in different types of cells and/or under different challenges.

The mechanisms underlying the dichotomous regulation of p53 by PAI- 1 in fibroblasts and ATII cells are unknown. Phosphorylation of p53 at serine 15 and 20 (serine 18 and 23 in rodents) prevents the binding of p53 to murine double minute 2, a major E3 ubiquitin ligase involved in p53 degradation, and thereby stabilizes the p53 protein. ${ }^{44,45}$ PAI-1 induces in ATII cells, but suppresses in fibroblasts, p53 ${ }^{\mathrm{S} 15 / 18}$ phosphorylation and p53 expression. ${ }^{15,20}$ In the current study, treatment with human PAI-1 reduced, whereas that with TM5275 increased, p53 phosphorylation at serine 15 and $\mathrm{p} 53$ expression in human lung fibroblasts (Figure 3A). In contrast to fibroblasts, silencing PAI-1 with PAI-1 shRNA reduced, whereas treatment with human PAI1 increased, p53 phosphorylation at serine 18 (equal to human p53 serine 15) and p53 expression in rat ATII (L2) cells (Figure 4A). These data suggest that one of the potential mechanisms whereby PAI-1 dichotomously regulates p53 expression in ATII cells and fibroblasts is divergent modulation of the expression/activity of protein kinase(s) involved in $\mathrm{p} 53$ phosphorylation.

Prostaglandin E2 (PGE2) has antifibrotic effects in the lung, and PGE2 levels are decreased in IPF. ${ }^{3,46,47}$ Fibroblasts from IPF lungs are more resistant to apoptosis compared with fibroblasts from control lungs. ${ }^{3}$ Additionally, treatment of fibroblasts from fibrotic lungs with PGE2 increases their apoptosis sensitivity. Conversely, treatment with PGE2 protects ATII cells from FasL-induced apoptosis. $^{3}$ Therefore, PGE2 deficiency is speculated to contribute to the increased sensitivity of ATII cells to apoptosis and the decreased sensitivity of fibroblasts to apoptosis in IPF lungs. Interestingly, there is a cross talk between plasminogen activation system and PGE2 
synthesis/function. ${ }^{47-49}$ PGE2 suppresses PAI-1 expression in human articular chondrocytes. ${ }^{48}$ Antifibrotic effects of plasmin occur via PGE2 synthesis in human and mice, ${ }^{47}$ whereas serpine1 (PAI-1) disrupts PGE2 production. ${ }^{49}$ Whether increased PAI-1 in IPF and/or aged mouse lung results from decreased PGE2 or whether PAI-1 divergently regulates the sensitivity of fibroblast and ATII cells to apoptosis through suppressing PGE2 synthesis in these cells warrants further investigation.

Because PAI-1 protein was deleted in whole body in PAI$1 \mathrm{CKO}$ mice, the protective effect of PAI-1 is not limited to fibroblasts and ATII cells. Several functions of PAI-1, besides inhibition of urokinase-type and tissue-type plasminogen activator activities, are well-documented, including modulation of cell adhesion and migration. The current study indicates that bleomycin-stimulated increase in the total cell number, especially the number of neutrophils, in BAL fluid is attenuated in PAI-1 CKO mice, further supporting the role of PAI-1 in modulation of cell adhesion and migration. These results also suggest that deletion of PAI-1 may attenuate bleomycin-induced lung fibrosis, in part, through reducing infiltration of inflammatory cells, a conclusion supported by the following observations. Treatment of experimental glomerulonephritis rats with mutant noninhibitory PAI-1 protein reduces extracellular matrix deposition in glomeruli, which is associated with a $46 \%$ decrease in the number of monocytes/macrophages. ${ }^{50}$ Additionally, neutrophil influx is significantly lower in PAI-1 knockout than in wild-type mice in an acute pyelonephritis model. ${ }^{51}$

Finally, PAI-1 may be an ideal therapeutic target for the treatment of fibrotic lung disease. Numerous studies have shown that PAI-1 expression is increased in IPF and in experimental lung fibrosis models and that this increased PAI-1 contributes to the development of lung fibrosis. ${ }^{13,15,17-20}$ However, no therapeutic drug targeting PAI-1 has been developed yet. In a previous study, oral administration of TM5275, 4 days after intranasal instillation of AdTGF- $\beta 1^{223 / 225}$, an adenovirus expressing constitutively active TGF- $\beta 1$, almost completely blocked TGF$\beta 1$-induced lung fibrosis in mice. ${ }^{15}$ Furthermore, administration of TM5275, 25 days after challenge with ovalbumin, significantly reduces ovalbumin-induced inflammation and airway fibrosis, ${ }^{52}$ suggesting that TM5275 may slow down or reverse the preformed fibrosis. In a recent study, TM5275 was shown to block bleomycin-induced rat ATII (L2) cell senescence, ${ }^{20}$ another pathologic feature of IPF lung. In a previous study ${ }^{13}$ and in this study, TM5275 promoted apoptosis in human and mouse lung fibroblasts. Together, these studies strongly suggest that PAI-1 may serve as an ideal therapeutic target for IPF and that smallmolecule PAI-1 inhibitors may have therapeutic potential for the treatment of fibrotic lung diseases.

In summary, the data presented in this study suggest that increased PAI-1 expression may contribute to the apoptosis paradox observed in IPF and aging lungs through dichotomous regulation of p53 expression in these cells. The results from this study further support a critical role of PAI-1 in IPF pathophysiology and suggest that smallmolecule PAI-1 inhibitors may have therapeutic potential for IPF.

\section{Author Contributions}

C.J. performed the experiments and analyzed the data; R.M.L. designed the study, analyzed the data, and wrote the manuscript; G.L., L.C., J.D., V.A., and V.J.T. contributed intellectually to the study, including the experimental design, data analysis, and manuscript writing and editing.

\section{Supplemental Data}

Supplemental material for this article can be found at http://doi.org/10.1016/j.ajpath.2021.04.003.

\section{References}

1. Barbas-Filho JV, Ferreira MA, Sesso A, Kairalla RA, Carvalho CR, Capelozzi VL: Evidence of type II pneumocyte apoptosis in the pathogenesis of idiopathic pulmonary fibrosis (IFP)/usual interstitial pneumonia (UIP). J Clin Pathol 2001, 54:132-138

2. Plataki M, Koutsopoulos AV, Darivianaki K, Delides G, Siafakas NM, Bouros D: Expression of apoptotic and antiapoptotic markers in epithelial cells in idiopathic pulmonary fibrosis. Chest 2005, 127:266-274

3. Maher TM, Evans IC, Bottoms SE, Mercer PF, Thorley AJ, Nicholson AG, Laurent GJ, Tetley TD, Chambers RC, McAnulty RJ: Diminished prostaglandin E2 contributes to the apoptosis paradox in idiopathic pulmonary fibrosis. Am J Respir Crit Care Med 2010, 182: 73-82

4. Moodley YP, Caterina P, Scaffidi AK, Misso NL, Papadimitriou JM, McAnulty RJ, Laurent GJ, Thompson PJ, Knight DA: Comparison of the morphological and biochemical changes in normal human lung fibroblasts and fibroblasts derived from lungs of patients with idiopathic pulmonary fibrosis during FasL-induced apoptosis. J Pathol 2004, 202:486-495

5. Hecker L, Logsdon NJ, Kurundkar D, Kurundkar A, Bernard K, Hock T, Meldrum E, Sanders YY, Thannickal VJ: Reversal of persistent fibrosis in aging by targeting nox4-nrf2 redox imbalance. Sci Transl Med 2014, 6:231ra247

6. Thannickal VJ, Horowitz JC: Evolving concepts of apoptosis in idiopathic pulmonary fibrosis. Proc Am Thorac Soc 2006, 3:350-356

7. Raghu G, Weycker D, Edelsberg J, Bradford WZ, Oster G: Incidence and prevalence of idiopathic pulmonary fibrosis. Am J Respir Crit Care Med 2006, 174:810-816

8. Fernandez Perez ER, Daniels CE, Schroeder DR, St Sauver J, Hartman TE, Bartholmai BJ, Yi ES, Ryu JH: Incidence, prevalence, and clinical course of idiopathic pulmonary fibrosis: a populationbased study. Chest 2010, 137:129-137

9. Fell CD, Martinez FJ, Liu LX, Murray S, Han MK, Kazerooni EA, Gross BH, Myers J, Travis WD, Colby TV, Toews GB, Flaherty KR: Clinical predictors of a diagnosis of idiopathic pulmonary fibrosis. Am J Respir Crit Care Med 2010, 181:832-837

10. Takeshita K, Yamamoto K, Ito M, Kondo T, Matsushita T, Hirai M, Kojima T, Nishimura M, Nabeshima Y, Loskutoff DJ, Saito H, Murohara T: Increased expression of plasminogen activator inhibitor1 with fibrin deposition in a murine model of aging, "Klotho" mouse. Semin Thromb Hemost 2002, 28:545-554 
11. Yamamoto K, Takeshita K, Kojima T, Takamatsu J, Saito H: Aging and plasminogen activator inhibitor-1 (PAI-1) regulation: implication in the pathogenesis of thrombotic disorders in the elderly. Cardiovasc Res 2005, 66:276-285

12. Yamamoto K, Takeshita K, Saito H: Plasminogen activator inhibitor1 in aging. Semin Thromb Hemost 2014, 40:652-659

13. Huang WT, Akhter H, Jiang C, MacEwen M, Ding Q, Antony V, Thannickal VJ, Liu RM: Plasminogen activator inhibitor 1, fibroblast apoptosis resistance, and aging-related susceptibility to lung fibrosis. Exp Gerontol 2015, 61:62-75

14. Olman MA, Mackman N, Gladson CL, Moser KM, Loskutoff DJ: Changes in procoagulant and fibrinolytic gene expression during bleomycin-induced lung injury in the mouse. J Clin Invest 1995, 96: $1621-1630$

15. Huang WT, Vayalil PK, Miyata T, Hagood J, Liu RM: Therapeutic value of small molecule inhibitor to plasminogen activator inhibitor-1 for lung fibrosis. Am J Respir Cell Mol Biol 2012, 46:87-95

16. Eitzman DT, McCoy RD, Zheng X, Fay WP, Shen T, Ginsburg D, Simon RH: Bleomycin-induced pulmonary fibrosis in transgenic mice that either lack or overexpress the murine plasminogen activator inhibitor-1 gene. J Clin Invest 1996, 97:232-237

17. Chuang-Tsai S, Sisson TH, Hattori N, Tsai CG, Subbotina NM, Hanson KE, Simon RH: Reduction in fibrotic tissue formation in mice genetically deficient in plasminogen activator inhibitor- 1 . Am J Pathol 2003, 163:445-452

18. Senoo $T$, Hattori $N$, Tanimoto $T$, Furonaka $M$, Ishikawa $N$, Fujitaka K, Haruta Y, Murai H, Yokoyama A, Kohno N: Suppression of plasminogen activator inhibitor-1 by RNA interference attenuates pulmonary fibrosis. Thorax 2010, 65:334-340

19. Zhang YP, Li WB, Wang WL, Liu J, Song SX, Bai LL, Hu YY, Yuan YD, Zhang M: siRNA against plasminogen activator inhibitor-1 ameliorates bleomycin-induced lung fibrosis in rats. Acta Pharmacol Sin 2012, 33:897-908

20. Jiang C, Liu G, Luckhardt $\mathrm{T}$, Antony V, Zhou Y, Carter AB, Thannickal VJ, Liu RM: Serpine 1 induces alveolar type II cell senescence through activating p53-p21-Rb pathway in fibrotic lung disease. Aging Cell 2017, 16:1114-1124

21. Horowitz JC, Rogers DS, Simon RH, Sisson TH, Thannickal VJ: Plasminogen activation induced pericellular fibronectin proteolysis promotes fibroblast apoptosis. Am J Respir Cell Mol Biol 2008, 38 $78-87$

22. Chang W, Wei K, Jacobs SS, Upadhyay D, Weill D, Rosen GD: SPARC suppresses apoptosis of idiopathic pulmonary fibrosis fibroblasts through constitutive activation of beta-catenin. J Biol Chem 2010, 285:8196-8206

23. Zhang YP, Wang WL, Liu J, Li WB, Bai LL, Yuan YD, Song SX: Plasminogen activator inhibitor-1 promotes the proliferation and inhibits the apoptosis of pulmonary fibroblasts by $\mathrm{Ca}(2+)$ signaling. Thromb Res 2013, 131:64-71

24. Shetty SK, Bhandary YP, Marudamuthu AS, Abernathy D, Velusamy T, Starcher B, Shetty S: Regulation of airway and alveolar epithelial cell apoptosis by p53-induced plasminogen activator inhibitor-1 during cigarette smoke exposure injury. Am J Respir Cell Mol Biol 2012, 47:474-483

25. Abderrahmani R, Francois A, Buard V, Tarlet G, Blirando K, Hneino M, Vaurijoux A, Benderitter M, Sabourin JC, Milliat F: PAI1-dependent endothelial cell death determines severity of radiationinduced intestinal injury. PLoS One 2012, 7:e35740

26. Gunther A, Korfei M, Mahavadi P, von der Beck D, Ruppert C, Markart P: Unravelling the progressive pathophysiology of idiopathic pulmonary fibrosis. Eur Respir Rev 2012, 21:152-160

27. Faner R, Rojas M, Macnee W, Agusti A: Abnormal lung aging in chronic obstructive pulmonary disease and idiopathic pulmonary fibrosis. Am J Respir Crit Care Med 2012, 186:306-313

28. Thannickal VJ, Murthy M, Balch WE, Chandel NS, Meiners S, Eickelberg O, Selman M, Pardo A, White ES, Levy BD, Busse PJ,
Tuder RM, Antony VB, Sznajder JI, Budinger GR: Blue journal conference: aging and susceptibility to lung disease. Am J Respir Crit Care Med 2015, 191:261-269

29. Redente EF, Jacobsen KM, Solomon JJ, Lara AR, Faubel S, Keith RC, Henson PM, Downey GP, Riches DW: Age and sex dimorphisms contribute to the severity of bleomycin-induced lung injury and fibrosis. Am J Physiol Lung Cell Mol Physiol 2011, 301:L510-L518

30. Bhandary YP, Shetty SK, Marudamuthu AS, Gyetko MR, Idell S, Gharaee-Kermani M, Shetty RS, Starcher BC, Shetty S: Regulation of alveolar epithelial cell apoptosis and pulmonary fibrosis by coordinate expression of components of the fibrinolytic system. Am J Physiol Lung Cell Mol Physiol 2012, 302:L463-L473

31. Bhandary YP, Shetty SK, Marudamuthu AS, Ji HL, Neuenschwander PF, Boggaram V, Morris GF, Fu J, Idell S, Shetty S: Regulation of lung injury and fibrosis by p53-mediated changes in urokinase and plasminogen activator inhibitor-1. Am J Pathol 2013, 183:131-143

32. Ghosh AK, Rai R, Park KE, Eren M, Miyata T, Wilsbacher LD, Vaughan DE: A small molecule inhibitor of PAI-1 protects against doxorubicin-induced cellular senescence. Oncotarget 2016, 7: 72443-72457

33. Sun T, Ghosh AK, Eren M, Miyata T, Vaughan DE: PAI-1 contributes to homocysteine-induced cellular senescence. Cell Signal 2019, 64:109394

34. Giacoia EG, Miyake M, Lawton A, Goodison S, Rosser CJ: PAI-1 leads to G1-phase cell-cycle progression through cyclin D3/cdk4/6 upregulation. Mol Cancer Res 2014, 12:322-334

35. Boncela J, Przygodzka P, Papiewska-Pajak I, Wyroba E, Osinska M, Cierniewski CS: Plasminogen activator inhibitor type 1 interacts with alpha3 subunit of proteasome and modulates its activity. J Biol Chem 2011, 286:6820-6831

36. Nakashima N, Kuwano K, Maeyama T, Hagimoto N, Yoshimi M, Hamada N, Yamada M, Nakanishi Y: The p53-Mdm2 association in epithelial cells in idiopathic pulmonary fibrosis and non-specific interstitial pneumonia. J Clin Pathol 2005, 58:583-589

37. Cisneros J, Hagood J, Checa M, Ortiz-Quintero B, Negreros M, Herrera I, Ramos C, Pardo A, Selman M: Hypermethylationmediated silencing of p14(ARF) in fibroblasts from idiopathic pulmonary fibrosis. Am J Physiol Lung Cell Mol Physiol 2012, 303:L295-L303

38. Akram KM, Lomas NJ, Forsyth NR, Spiteri MA: Alveolar epithelial cells in idiopathic pulmonary fibrosis display upregulation of TRAIL, DR4 and DR5 expression with simultaneous preferential overexpression of pro-apoptotic marker p53. Int $\mathrm{J}$ Clin Exp Pathol 2014, 7:552-564

39. Kunz C, Pebler S, Otte J, von der Ahe D: Differential regulation of plasminogen activator and inhibitor gene transcription by the tumor suppressor p53. Nucleic Acids Res 1995, 23:3710-3717

40. Shetty S, Shetty P, Idell S, Velusamy T, Bhandary YP, Shetty RS: Regulation of plasminogen activator inhibitor-1 expression by tumor suppressor protein p53. J Biol Chem 2008, 283:19570-19580

41. Overstreet JM, Samarakoon R, Meldrum KK, Higgins PJ: Redox control of p53 in the transcriptional regulation of TGF-betal target genes through SMAD cooperativity. Cell Signal 2014, 26:1427-1436

42. Samarakoon R, Higgins SP, Higgins CE, Higgins PJ: The TGFbeta1/p53/PAI-1 signaling axis in vascular senescence: role of caveolin-1. Biomolecules 2019, 9:341

43. Bhandary YP, Shetty SK, Marudamuthu AS, Midde KK, Ji HL, Shams H, Subramaniam R, Fu J, Idell S, Shetty S: Plasminogen activator inhibitor-1 in cigarette smoke exposure and influenza A virus infection-induced lung injury. PLoS One 2015, 10:e0123187

44. Maclaine NJ, Hupp TR: The regulation of p53 by phosphorylation: a model for how distinct signals integrate into the p53 pathway. Aging 2009, 1:490-502

45. Chao CC: Mechanisms of p53 degradation. Clin Chim Acta 2015 , 438:139-147

46. Lappi-Blanco E, Kaarteenaho-Wiik R, Maasilta PK, Anttila S, Pääkkö P, Wolff HJ: COX-2 is widely expressed in metaplastic 
epithelium in pulmonary fibrous disorders. Am J Clin Pathol 2006, 126:717-724

47. Bauman KA, Wettlaufer SH, Okunishi K, Vannella KM, Stoolman JS, Huang SK, Courey AJ, White ES, Hogaboam CM, Simon RH, Toews GB, Sisson TH, Moore BB, Peters-Golden M: The antifibrotic effects of plasminogen activation occur via prostaglandin E2 synthesis in humans and mice. J Clin Invest 2010, 120: $1950-1960$

48. Masuko K, Murata M, Suematsu N, Okamoto K, Yudoh K, Shimizu H, Beppu M, Nakamura H, Kato T: A suppressive effect of prostaglandin E2 on the expression of SERPINE1/plasminogen activator inhibitor-1 in human articular chondrocytes: an in vitro pilot study. Rheumatol 2009, 1:9-15

49. Blaha M, Nevoral J, Prochazka R: The serine protease inhibitors and SERPINE1/2 disrupt prostaglandin E2 production and hyaluronic acid retention in FSH-stimulated pig cumulus-oocyte complexes. Reprod Domest Anim 2019, 54 Suppl 4:65-68

50. Huang Y, Haraguchi M, Lawrence DA, Border WA, Yu L, Noble NA: A mutant, noninhibitory plasminogen activator inhibitor type 1 decreases matrix accumulation in experimental glomerulonephritis. J Clin Invest 2003, 112:379-388

51. Roelofs JJTH, Teske GJD, Bonta PI, de Vries CJM, Meijers JCM, Weening JJ, van der Poll T, Florquin S: Plasminogen activator inhibitor-1 regulates neutrophil influx during acute pyelonephritis. Kidney Int 2008, 75:52-59

52. Liu RM, Eldridge S, Watanabe N, Deshane J, Kuo HC, Jiang C, Wang Y, Liu G, Schwiebert L, Miyata T, Thannickal VJ: Therapeutic potential of an orally effective small molecule inhibitor of plasminogen activator inhibitor for asthma. Am J Physiol Lung Cell Mol Physiol 2016, 310:L328-L336 